\title{
Arany János ismertsége a finnek körében
}

1. Mondani szokás, hogy az éremnek két oldala van, még ha az az érem „Arany” is. A mi kérdésünk is kétoldalú: mit tudott Arany a finnekről és mit tudtak a finnek Aranyról. A finn szó elhangzásakor a magyarok eszébe elsőként általában a Kalevala jut, nem véletlenül. Az eposz müfaj komoly magyar filológiai múlttal rendelkezö történetét a Kalevala kérdéskörben tipródva sokan vizsgálták, éppen Arany ürügyén: hogyan viszonyult Arany konkrétan a finn eposz keltette müfajproblémához, a magyar eposz hiányához, a naiv eposzhoz, az eposzi hitelhez. A tisztánlátás elösegítése ebben a nagy múltú és ellentmondásos kérdésben itt és most nem lehet feladatunk.

2. A finnek Aranyról mikor mit tudhattak, mit olvashattak - tőle és róla, éltében-holtában? Egy kétszáz éves évforduló kapcsán ez az időtartam és ez a feladat ijesztő. A kutatás forrásmunkái között elsőként kell említenünk VILJO TERVONEN (1917-2011) munkáit. 2017 májusában, születésének 100. évfordulóján is köszönettel emlékezünk rá. Közel másfélezer tételt tartalmazó bibliográfiával, magyar és finn tudósok levelezéseit közreadó kötetekkel, új adatokra épített cikkekkel járult hozzá annak kutatásához, hogy a finn nyelvü ,'́rásbeliségben” a magyarok mikor, hogyan szerepeltek.

Arany János neve még éltében felbukkant a finn napilapok irodalmi leveleiben, a tudósításokban, gyorshírekben, amelyek szerzője többnyire, de nem mindig a „magyar Matti” (Unkarin Matti; f. Matti 'Mátyás'), vagyis SzINNYEI JózSEF, illetve barátja, ANTTI JALAVA, a „finn Matti”. Akadnak névtelen vagy nehezen azonosítható szerzőjü írások is, mert a finn nyelvü (és gyakran gót betüs) sajtóban az 1870-es, 80-as években még nem ritkán csak monogramok álltak a cikkek végén. Megjegyzendő Arany János ürügyén is, hogy teljességre törekvést érdemelne a svédországi svéd nyelvü (mint hírforrás), a finnországi svéd nyelvü és finn nyelvü sajtó, illetve szakirodalom módszeres kutatása és egybevetése.

Forrásnak tekinthetők a finn lexikonok, a finn (világ)irodalomtörténetek, amelyekben szerény méltató sorokat vagy említést találunk Aranyról. Ezek azonban nem lebecsülendő apróságok, a finn nép ugyanis olvasó nép volt. Kiemelkedő példa az 1890-ben alapított finn érzelmü - és magyarbarát - Otava könyvkiadó által gondozott lexikonban (Tietosanakirja 1909) az Aranynak szentelt szócikk, amelyben a költő arcképeként a Nemzeti Múzeum elé 1893-ban állított pompás [f. komea] szobor feje látható. A név helyes ejtése is ott van: aranj jānoš. Megtudható, hogy ő volt „Magyarország legkiemelkedőbb költője Petőfivel és Tompával egy sorban, és egyben első mint epikus és balladaköltő; erőteljes, sokoldalú, jól megformált költészetében, amelynek alapja a hazai népköltészet [...] mesterien mutatta be a magyar nép természetét. Fő müvében, a nagy népi eposzban [!] - Toldi 1847, Toldi szerelme (Toldin rakkaus, 1879), Toldi estéje (Toldin elämän ehtoo [Toldi életének alkonya vagy Toldi alkonya] 1854) - amelyben a hős és boldogtalan Toldi 
regés történetét előadva többrészes, színes és érzelemgazdag képet adott a magyar középkorról, a lovagvilágról. A Buda király [!] halála (Kuningas Budan kuolema 1864) címü eposzában a két hun királyi testvér, Buda és Attila harcát mutatta be. A legmagasabb szintre komor, tragikus balladáiban jutott, ugyanakkor viszont írt szatirikus eposzt, románcot, lírai verset, tanulmányokat (például Zrínyi és Tasso), kritikákat is, és mesterien fordított (Shakespeare-t és főleg Arisztophanészt). Prózai munkái bizonyítják, hogy szakavatott irodalomtörténész és kifinomult érzékü esztéta volt.” Ez a velős szócikk valószínúleg ,vándorlásba” kezdett - lexikonból lexikonba, és forrása lett több későbbi Arany-életrajznak is.

3. Egy irodalmi nagyság megismerésének mindig is voltak elősegítő és hátráltató tényezői. Íme mindegyikre egy-egy példa: elősegítő ,a helyzet” - a hátráltató Petőfi és Jókai.

3.1. Az Arannyal ismerkedő fél állapotát és igényeit illetően egy pillantást kell vetnünk a finnek és a finn nyelv helyzetére. A magyaroknak meglepő a „finnség mint olyan” fiatal volta. A cári birodalom svéd és finn nyelvü Autonóm Finn Nagyhercegségében (1809-1917) az erősödő orosz nyomást érezve a finn érzelmü, de műveltségét nagyrészt svédül szerzett és svéd módra élő értelmiség Arany életének utolsó évtizedében, sőt, éveiben (!), természetesen nem tőle függően, de a magyar történeti tapasztalatokat (is) (meg)ismerve, ébredt rá arra, nem elöször, de utoljára, hogy „itt az idő”: finné kell válni - most vagy soha! Sőt, a két nyelvet beszéló [kaksikielinen] népnek egyet értőnek [yksimielinen] kell lennie és benne az egységes hazafiságnak [yhtenäinen isänmaallisuus] kell megtestesülnie ezek a finn(országi) nemzeti(ségi) mozgalom, a fennománia alapelvei.

A fennománok (,mániákusan finnek”) a magyarokra mint sok tekintetben mintaként-példaként szolgáló „,rokonokra” tekintettek, de a magyarul tudó, müfordítói munkára vállalkozó és erre alkalmas finnek száma érthetően minimális volt. Amikor a svédek a finnek ázsiaiságát emlegették, és tudatosult a finn értelmiség elsvédesedésének, illetve a finn nép esetleges eloroszosításának veszélye, egy külföldi költőóriás népszerüsítése, még ha magyar is, egyre kevésbé tünt időszerünek, ,aktuálpolitikainak” pedig különösen nem, mivel a költőóriás nem volt a szó szoros értelmében programadó forradalmár, és mert fó célkitüzésük a saját finn nyelvü szépirodalom megteremtése és „felfuttatása” (menedzselése) lett, magyarán a finn irodalmi nyelv megteremtése, az egységes helyesírás rögzítése - ez pedig a finnségi mozgalom „belügye” volt. Az egész „finn Arany”-történetben tehát már a kezdeteknél találkozunk az aktualitás, az időszerüség kérdésével.

3.2. A finnek körében az Arany iránti érdeklődést huzamos időt át hátráltató tényező - bizonyára meglepő, sőt megdöbbentő módon - Petőfi volt, az időrendben elsőként közismertté vált, a csatában elesett barát, a költő és forradalmár Petőfi, valamint a müfordítás szempontjából könnyebb „zsákmány”, a novella és a regény müfajában kiemelkedő Jókai. Mindkettejük finnországi ismertségét IRENE WICHMANN vizsgálta cikkeiben és disszertációjában, amelynek függeléke a 19. században finnre fordított Petőfi-versek listája (WICHMANN 2009, 2015). A helyzet később is, mindvégig ,;óindulatúan ellentmondásos”. A finn nagyközönségnek szánt Heimokirjában (Finnugor könyv, RÄIKKÖNEN 1924) például ez áll: „Ma- 
gyarország szellemi élete döbbenetesen gazdag. Már a 13. században vannak írásos magyar nyelvmutatványok. És az utóbbi évszázadokban a magyar irodalom magas szintet ért el, ragyogó neveket, európai hírességeket is adván. Mindenekelött nálunk is ismertek az olyan nevek, mint Vörösmarty Mihály, Eötvös József és Petőfi Sándor". (A szöveghez mellékelve Petőfi legkackiásabb bajszú arcképe.) Arany nevét nem a felsorolásban nem találjuk.

4. Áttekintve az ismeretszerzés korszakait, úgy látjuk, hogy Arany finnországi ismertségének történetében a „keresletet és kínálatot” meghatározó, különféle politikai, kultúrpolitikai, eszmetörténeti, országismereti és nem utolsó sorban nyelvismereti háttér-tényezőknek köszönhetően öt szakasz rajzolódik ki: 1. a fennománia ideje; 2. az 1920-as és 30-as évek; 3. 1952; 4. 1970; 5. a 2000-es évek.

4.1. Az első az imént említett fennománia politizálódásának ideje - Arany életében és közvetlen utána. Ezt a kort jól szemlélteti az alábbi sajtószemle és az első fordítások története.

4.2. A két világháború közötti gyökeres változások az Arany-életmű megismerésének csak módjával kedveztek. Az 1917-1920 között függetlenné vált és a véres polgárháború (1918 tavasza) után megszilárdult finn állam kultúrpolitikusai értelemszerüen előre néztek, a saját, „független” finn arculat megteremtése és nemzetközi elfogadtatása volt a cél. Ez nem jelentett elzárkózást, inkább újfajta együttmüködést minden égtáj irányában. A magyar-finn kapcsolatok állami támogatásban részesültek, föként az „expanzív kultúrdiplomáciának” köszönhetően. Ennek alapelve nálunk Klebersberg Kunó, a finneknél a politikusként is aktív nyelvész E. N. Setälä megfogalmazásában vált ismertté: a kultúra az emberiség közkincse és egyúttal hazafias, nemzetvédelmi kérdés, mert az ún. kisnépek csak a müveltségükkel vívhatnak ki helyet maguknak a „nagy” „kultúrnemzetek” között, a kultúra nem fölényt biztosít, hanem védelmet nyújt (SzíJ 1991: 72-88).

A magyarság és a magyar kultúra megismertetéséből kivették részüket az idők során Finnországba került és ott élő magyarok és magyar feleségek, például Faragó József, Yrjö Wichmann-né Hermann Júlia (a néprajzi szakirodalomban Julie Wichmann) vagy Weöres Gyula, illetve a finnugor néprokonsági mozgalomban [heimotyö] is aktív magyarországi magyarok közül föleg Bán Aladár. Említendő a mindenkori diplomáciai képviseletek segítsége is.

4.3. Az 1944 végén alapított Finnország-Szovjetunió Társaság (Suomi-Neuvostoliitto Seura) után a következő engedélyezett finnországi civil tömörülés az 1950-ben alapított, ma is hatékonyan müködö, országos hatókörü Finn-Magyar Társaság (Suomi-Unkari Seura) lett, amelynek rendezvényein (pl. március 15-én mindig), kiadványaiban helyet kaptak a magyar irodalom klasszikusai is. Például terjedelmes tudósítás jelent meg A nagy magyar epikus, Arany János halálának 70. évfordulója címmel - a Toldi 1. énekének kíséretében - a Suomi-Unkari c. lapjuk 1952. decemberi számában. 1982-ben ugyanitt jelent meg két részletben KERESZTURY DEZSÖ írása, Arany János - a magyar Goethe címmel.

A Finnország-Szovjetunió Társaság és a finn baloldali pártszövetség volt a tulajdonosa a Kansankulttuuri [Népkultúra] könyvkiadónak. Kiadványai között egyfajta kuriózum az 1952-ben közreadott Vapauden tulet [A szabadság tüzei] 
címü, kisméretü, 110 oldalnyi, ma már ritkaságszámba menő magyar antológia, amely négy nagyság: Petőfi, Arany, Ady, József Attila verseiből adott közre válogatást (TURTIAINEN toim. 1952). Mind a szerkesztö, mind a versek fordítói a finnországi baloldali irodalom történetéből, illetve a párttörténetből „saját jogon” ismerös nevek: Elvi Sinervo, Aira Sinervo-Brink, valamint ARVO TURTIAINEN, az Előszó szerzője, a kötet szerkesztője, a költőkről szóló ismertetések írója. Nem tudtak magyarul, és (még) nem ismeretes (nekünk), hogy kik válogatták ki a verseket, a nyersfordításokat kiktől kapták. A cím nem szorul indoklásra: a szövegekben gyakorta szerepel a tüz [tuli] és vörös színü lángja [punavärinen liekki]. Az eszmei mondanivaló egyértelmü: „Ezen négy csillag [a négy költő] mindegyikének az alapszíne [ydinväri] mindig egy és ugyanaz volt: különböző árnyalatokban, mindegyikük mindig éppen a maga korára tipikus módon sugározta [sädehtivät] az emberi szabadságszeretetnek és a társadalmi haladásvágynak világszerte alapszínét [perusväri], a félt [pelättyä] és szeretett [rakastettua] vöröst [punaista]”.

A kötetben nemcsak a fordítások, a fordítók nevezetesek, hanem a szerkesztő TURTIAINEN által megrajzolt Arany-kép is. Nem tudjuk, mi vagy ki volt TURTIAINEN forrása. Az Öszikékre magyar és finn szóval hivatkozásából ítélve volt magyar segítsége. Említette Arany sokoldalúságát, fordítóként, esztétaként is méltatta, majd meglepő, de nem minden igazság nélküli fordulattal zárta az írást: „Nyelvi zsenialitásáról meggyőző képet adnak fordításai - Shakespeare, Arisztophanész stb. Tanulmányai bizonyítják, hogy a magyar nyelv és irodalom legalaposabb ismerője, valamint a kritikai esztétikának is képviselője. Élete vége felé lírája még egyszer magaslatokba emelkedik. A »Kapcsos könyvében « [Helakantinen kirja] közreadott verseinek, az »őszikék« (Syksyiset) versciklusának minden egyes darabja megindító panasza [liikuttava valitus] annak az embernek, akinek az életét megkeserítette a szabadság és az alkotási lehetőségek hiánya." A szabadság hiánya másként értendő, ha tudjuk, hogy a fordítók a szovjet-finn ún. folytatólagos háború (1941-1944) idejét a katonai szolgálat megtagadása miatt fegyházban töltötték. A kiadványba a következő Arany-versek kerültek be: a Családi kör, A walesi bárdok, a Civilizáció, Dal fogytán, Intés, „Rendületlenül” (ez utóbbi a címében idézőjellel és Vörösmartyra utaló jegyzettel ellátva, miként jegyzetet kaptak a bárdok is). Sajnálatos, hogy A walesi bárdokban a versszakok némileg összekeveredtek.

4.4. 1970-ben Unkarin lyyra [Magyar költészet] címmel egy igazi antológia jelent meg (LYY toim. 1970). Ez is kuriózum: egyrészt tartalmilag első és egyedülálló áttekintése a magyar költészetnek az Ómagyar Mária-siralomtól a kortársakig, kb. 60 szerző bemutatásával. Másrészt pedig újabb, de a korábbiakat sajátosan ismétlő ellentmondások közepette készült: a jóléti állammá váló Finnország modernizálódni akart, felzárkózni a kulturális szabadosság jeleit mutatni kezdő egyetemes (nyugati) kortárs kultúrához. A magyar-finn kapcsolatokat a kétféle társadalmi rendszer közötti külpolitikai és kultúrpolitikai nyitás jellemezte. Kívánalom lett a „rugalmas” elszakadás a „klasszikustól”, a magyarokat illetően az álmagyartól is, amely a 19. század utolsó harmadában - finn okokból érthetően sikeres népszínmüvek (ál)magyarságképének makacs továbbélésében volt megfigyelhető. Ez a máig egyetlen magyar költészettörténeti antológia a finn-magyar kulturális egyezmény keretében készült, a magyar szerzőket, müveket a magyar 
fél javasolta a finneknek. A fordító Toivo Lyy nyersfordításokból és konzultánsokkal dolgozott. A kötet végén megtalálható a szerzők meglehetősen részletes életrajza, így Arany Jánosé is.

A kötet fogadtatását - miként a két világháború közötti magyar-finn irodalmi kapcsolatokat egészében - YRJÖ VARPIO és SzOPORI NAGY LAJOS tüzetesen vizsgálta közös, magyarul is, finnül is megjelent könyvében (1990a, 1990b). Arany neve nem maradhatott ki a Madách-csal foglalkozó finn(országi) kutatásokból sem, így GEREVICH-KOPTEFF ÉvÁnak a Tragédiával és a fordító Toivo Lyy személyével foglalkozó disszertációjából (2003) sem, miként a Toivo Lyy név sem a Tragédia finn fordítójaként a magyar irodalomtörténetből.

Arany neve felbukkant olyan kiadványban, amelyre nem is gondolnánk: ez a magyar gyerekirodalom, amelynek finn nyelvü közreadásában egy régi „hagyománynak", a vegyes házasságnak is nyilvánvaló a szerepe. A válogatás, a fordítás a finn-magyar gyermekek apjának, az Ady-szakértőként megismert Tuomo Lahdelma irodalomprofesszornak a munkája. A Viluinen kuningas [A didergő király; 1990] címü válogatás szerzőgárdája: Arany, Babits, József Attila, Kányádi, Kosztolányi, Móricz Zsigmond, Nemes Nagy Ágnes, Petőfi, Szabó Lőrinc, Weöres Sándor. Aranytól a Toldi estéjének csak az első négy sorát (az első sort címként is) és a Családi kört találjuk meg benne, ezt viszont a 9-12. versszak kihagyásával, mivel a honvéd vendég története a gyerekkönyvekben szokatlan történelmi magyarázkodásra szorulna.

4.5. Az új évezred leginkább szó szerint veendő újdonságokkal szolgált - tartalmi és technikai értelemben egyaránt. Ismeretforrásként az internet, a honlapok, a szórólap is felzárkózott a hagyományos módok mellé.

A Finn-Magyar Társaság évente négyszer megjelenő újságjában Sinikka Pohjola fordításában megjelent két Arany-ballada: az egyik a Bor vitéz új, modern fordítása (2001, 1. alább is), a másik pedig (2003) a Mátyás anyja - finnül első ízben és egyben a magyar eredetivel együtt. KOVÁCS MAGDOLNA hozzá írt magyarázatából tanulságos újdonság a megjegyzés: ez az a ritka Arany-ballada, amelynek jó a vége.

A számítógépes világban egy kattintással az igaz ismeretek mellett vagy helyett a hibák is széles körben ismertté, örökéletűvé és hatásossá válnak, a helyreigazításhoz egy kattintás már kevés. A legkézenfekvőbb finn internetes oldalakról (pl. wikipedia.org, wikiwand.com) megtudható, hogy Arany magyar költő, a balladák Shakespeare-je, több mint 40 balladát írt, amelyeket 50-nél több nyelvre fordítottak le, a Toldi-trilógia (1847) [sic] is megemlítődik, és megtudjuk, hogy „részvételéért a forradalmi tevékenységben börtönbe került. Nem sokkal ezután lefordított három Shakespeare-darabot magyarra. Azt mondják, hogy a börtönben az angol és a német biblia összehasonlításával tanult meg angolul” [Kerrotaan hänen opetelleen englantia vankilassa vertailemalla englanninkielistä ja saksankielistä Raamattua toisiinsa]. Az életmű méltatása ennyi: az egyik budapesti metróállomás a költő nevét viseli, egy ugyancsak róla elnevezett utcánál.

A Finn-Magyar Társaság sokak által látogatott honlapján a magyar irodalom egészének és benne Aranynak a megismerhetőségét több, rövid és velős aloldal teszi lehetővé. Így például a magyar irodalomtörténet 2. részéhez tartozó szerzőbemutatónál - SANNA TIIRIKAINEN nevével fémjelezve - megtudható, hogy „Arany 
János leginkább lírájáról és 40-nél több balladájáról ismert. Sikerei a Toldi címü elbeszélő költeménnyel kezdődtek (1847), és később a müveit szorgalmasan fordították más nyelvekre. Kihívást jelentő [haastava] és töprengő [pohdiskeleva], ritkán azonnal megnyíló [harvoin kerralla aukeava] mủvek jellemzik. Verseiben harmóniára törekvés [harmonian tavoittelu], szubjektivitás [subjektiivisuus] és elemző hajlam [analyyttinen ote] figyelhető meg. Ideálja a népköltészet volt, müveihez inspirációt nyert belőle. Továbbá korának egyik legjelentősebb müfordítója volt".

A magyar irodalmi klasszikusok megismertetésében a kultúrdiplomácia hagyományos szerepe ma sem lebecsülendő. A 2012-es könyvfesztivál díszvendége Helsinkiben Magyarország volt. Nagyszámú látogató kezébe került egy szórólapszerü, rövid, de velős áttekintés a magyar irodalomról - SZEGÖ JÁNOS munkája, a magyar irodalmat magyarul is jól ismerő Anna Tarvainen fordításában. A szöveg új vonásokkal gazdagítja a már megszokott Arany-képet [itt most finnből fordítva vissza magyarra - Sz. E.]: „Arany folytatta legjobb barátja, Petőfi törekvéseit a népköltészet terén, és a nemzeti klasszicizmus szorításában kezdte megalkotni a modern magyar lírát. Petőfi mellett mindig ő a másik örök klasszikus [Petőfin ohella hän on toinen ikuinen klassikko]. Elbeszélő költeményeiben, versregényeiben és lenyügözően komor balladáiban magyar történelmi eseményekröl írt puritánul, de ugyanakkor igézően gazdag szóhasználattal, teljességgel uralván a formát. Utolsó balladáiban már a modern nagyváros szürrealista világa is mutatkozik, ilyen például a Híd-avatás [f. Sillan vihkiminen 1877], amelyben megörökítette az új híd használatba vételét és a [a résztvevők] összeomlását. Ez azonban Aranynak csak az egyik oldala. A másikon vérfagyasztó iróniával és öniróniával mutatkozik meg, ezzel folytatva harcot [hän käy taistelua] az országra jellemző elzárkózó mentalitás, a múltfelejtés és a fennhéjázó faragatlanság ellen [maan mentaliteetille tyypillistä sulkeutuneisuutta, menneisyyden unohtamista ja pöyhkeää moukkamaisuutta vastaan]. Saját zsenialitásának foglya lett. [...] Arany fordításában a Hamlet igazi magyar klasszikus."

A „legújabb kori” Arany-fordítás Eliisa Pitkäsalóé, a Szondi két apródja [Szondin kaksi paashipoikaa]. Finnországi ismertségéről (még) nem tudunk, mert 2012-ben nem finn, nem finn-magyar, hanem magyar-finnugor típusú és egyben többnyelvü - pontosabban több finnugor nyelvü - vállalkozás eredményeként Magyarországon, a Füzfa Balázs által kiválasztott és A 12 legszebb magyar vers címet viselö reprezentatív kötetben jelent meg (Pitkäsalo 2012), amely a jelenkori finnugor kulturális együttmúködés egyik szép magyar példája: az apródok története - az eredetit is beleértve - hét finnugor nyelven, köztük finnül is megismerhetővé vált. A hasonló módon kiválasztott 50 legszebb magyar vers között (FÜZFA szerk. 2015) Aranytól még a Mindvégig szerepel, de ennek finn fordításáról nem tudunk.

5. Nagyon is fontos kérdés, hogy honnan ismerte a fordító a fordítandó müvet: a müfordítás közvetítő nyelv, személy segítségével vagy pedig egyenesen az eredetiből készült-e, csak nyelvismerettel és/vagy országismerettel is? Itt és most csak annyit: a legelső és a legutolsó finn Arany-fordítások biztosan a magyar eredetiből készültek. 
5.1. A legelső fordításokat illetően a kérdés így is feltehető: mit tud(hat)tak a finnek Aranyról? Voltak-e Aranynak élö-eleven finn ismerősei, akik esetleg Arany személyes hatására kezdtek fordítani? Egyáltalán: tudtak-e magyarul? Nem árt átismételnünk az Arany-életrajz ,pesti felének” időrendjét, hogy felmérjük, mit illene tudnunk Arany életének arról a szakaszáról, amikor egyre gyakrabban fordultak meg nálunk a finnek, azok, akiket a kapcsolattörténetben „hídépítőkként” vagy ,a tudomány apostolaiként” szokás emlegetni - ez a tudománnyá vált finnugrisztika történetének fontos korszaka.

A Magyar Tudományos Akadémia 1858 decemberében kezdhetett újra alapszabály szerint müködni, „,sak ekkor” lett Arany levelező és azonnal rendes tag, vagyis akadémikus (1858. dec. 15.). A további dátumok: 1860. júl. 5. a Kisfaludy Társaság igazgatója és Pestre költözése; 1860 novemberétől a Szépirodalmi Figyelő szerkesztése, írása, kiadása (1863-tól Koszorú néven); 1865. jan. 26. az Akadémia titkára, 1870. jan. 17. fötitkár, 1877 lemondása, 1879 a lemondás elfogadása; 1882. okt. 22-én 65 éves korában elhunyt, okt. 24-én temették.

A kérdésre, hogy voltak-e olyan finnek, akik az élö-eleven Aranyt ismerték, ismerhették, a felelet: voltak, lehettek. Csupa olyan „nagy” név, amelyeket megtalálunk bármely lexikonban. Itt járt, illetve nem ritkán hosszasan itt tartózkodott: 1862-ben August Ahlqvist (1826-1889); 1865 ősze - 1866 nyara közt Oskar Blomstedt (1833-1871) családostul; 1867 és 1872 folyamán Otto Donner (18351909); 1875, 1881, 1886, 1895, 1899 és 1903 folyamán Antti Jalava (1906-ig Almberg néven is; 1846-1909) néha családostul; 1878 késö tavasza - 1879 nyara közt Arvid Genetz (Arvi Jännes; 1848-1915) családostul.

Nehezen képzelhető el, hogy a Pesten megforduló, az Akadémián előadó tudós finnekre „ügyet sem vetett volna”, intézve például az akadémiai könyvtár finn csereügyeit. Csakhogy a főtitkár Arany az akadémia rabszolgájaként aligha ért rá velük „külön” foglalkozni, föleg, hogy az 1870-es években már megfáradt, beteg ember volt, és voltak mások - nyelvészek, irodalmárok, más „finnisták” -, akik a finnek gondját viselték (Hunfalvy, Budenz, Gyulai Pál, a két Greguss, Barna Ferdinánd stb). Ha belenézünk GAZDA IsTVÁNnak az életrajzkutatók számadatait is összesítő cikkébe (2008) vagy elolvassuk GÁBORI KOVÁCS JÓzSEF Tudományszervező költő az Akadémián címmel, a jubileum nyitányaként elhangzott előadását (2017), érthető Arany megjegyzése, hogy csak a számára hivatalból kötelezö ülésekre ment el. És itt utalunk egy félreérthetőségre, mivel a szereplők nem akárkik: a nyelvész Ahlqvist Pestről 1862. ápr. 28-án Pestről megírta Elias Lönnrotnak [Ahlqvist 1982: 105], hogy 1859 óta mindketten a magyar akadémia tagjai, csakhogy erröl nem értesültek, ő is csak most, mivel az értesítés ,,az akkori titkár elmondhatatlan gondatlansága miatt elküldetlen maradt" [,,kutsumus-kirja [!] on silloisen sihteerin sanomattomasta huolimattomuudesta jäänyt lähettämättä"] - ,,az akkori titkár” nem Arany volt.

5.2. Egy kis finn sajtószemle keretében képet kaphatunk arról, mit tudhattak meg az újságolvasó finnek Aranyról. Az általában négyoldalas finn nyelvü újságokra jellemző volt a müfaji sokféleség: a részben gót betüs finn nyelvü cikkek között voltak pármondatos apró hírek, kuriózumokról tudósítások, elmélyült tanulmányok, nemzetpolitikai programok, stb. Aranyról, leginkább az emberről - itt, most a megjelenések időrendjében idézve - például a következőket olvashatták. 
1880. 05. 18. Suomen Wirallinen Lehti 58: 2. Arany a pesti egyetem díszdoktora.

1881. 08. 07. Uusi Suometar [a címoldalon csak Suometar - Sz. E.] 153: 2-3. A 143. sz. levél Helsinkiből. - A Finn Irodalmi Társaság (SKS) alapításának 50. évfordulója tiszteletére 1881. július 5-vel kezdődően többnapos, országos, sőt nemzetközi ünnepségen a magyarok nem képviseltették magukat. Arvid Genetz javaslatára mégiscsak emelték poharukat a helyi nagyságok, Topelius és Oksanen (A. Ahlqvist) mellett Magyarország legnagyobb élő költőjének, Arany Jánosnak [f. Juhana Arany] az egészségére.

1882. 11. 03. Helsingin Wiikko-Sanomat 44: 4. - A Külföldröl rovatban kétféle pármondatos hír jelent meg, elsőként egy egyiptomi, másodikként a következő: „A magyar költő, Arany, a pesti akadémia tagja a múlt hónap [október - Sz. E.] 22-én elhunyt".

1882. 11. 11. 263. sz. és 1882. 11. 14. 265. sz. Uusi Suometar. - Antti Jalava XXII. leveleként, a címoldalon kezdve kétrészes, alapos és - ha lehet ilyet mondani - szívélyes nekrológot jelentetett meg. Az 1881. okt. 31-i levelében már megírta, hogy a Petőfi-szobor avatásán Arany már nem tudott részt venni, és egy majdani Arany-szobrot is említve (erről újra 1. 1883. 04. 11.) erősítette a hagyományt, hogy Petőfi és Arany neve „,finnül” is elválaszthatatlan legyen. A nekrológ végén Genetzet további Arany-fordításokra biztatta (1. alább).

1882. 11. 13. Suomalainen Wirallinen Lehti 264: 2 . Az egy császárnét és egy királynét illető egy-egy összetett mondat után áll a tudósítás, hogy „Az elhunyt magyar költő, Arany után maradt tulajdont nagyon nagynak mondják. Íróasztalának fiókjából többek között előkerült egy füzet, tele eddig ismeretlen szerelmes dalokkal, amelyeket a menyasszonyának írt [alább erről másként - Sz. E.]. A költő vagyonát 100000 forintnak számolták, az egykori vándorszínész (író)tollának köszönhetően meggazdagodott."

1883. 04. 11. Uusi Suometar 82: 1. - Az Uusi Suometar magyarországi levele címmel Unkarin Matti (ti. SzINNYEI) a leendő millenniumi ünnepségekről szólva írta, hogy „talán akkor lelepleznek egy új szobrot [kuvapatsas], éspedig legkiemelkedőbb [etewin] költőnk, Juhani Arany szobrát, amelyre pár hónap alatt 33 ezer gulden, vagyis finn pénzben közel 100 ezer márka gyült össze. [Az Aranyszobor avatására 1893-ban került sor - Sz. E.] Ti már ismeritek Aranyt abból a kellemes [miellyttävä] elbeszélésből, amelyet A. Jalava adott közre róla pár hónapja az Uusi Suometarban. - Bizonyára azt a furcsaságot is tudjátok, hogy Arany apó [ukko Arany] nem tett közzé sosem szerelmes verseket. Mi magyarok is furcsálltuk ezt, és nem is akartuk elhinni, hogy ne írt volna ilyeneket. - Nem is tévedtünk, mivel halála után kiderült, hogy egész csomó szerelmes verse van, amelyeket a feleségének írt, de amilyen szégyenlős volt, sosem akarta publikálni őket. Kivéve azt a néhányat, amelyeket saját megzenésítésében hagyott hátra. Az utolsó időkben, amikor az apó [ukko] már csaknem vak volt, és egyébként is folyton beteges, egyedüli vigasza a gitár [gitarri] volt, amellyel népdalokat és saját szerzeményeket adott elő olyankor, amikor azt hitte, hogy egyedül van, hallgatóság nélkül. Ezeket a dallamokat a múlt hónapban előadták a Kisfaludy Társaságban, 
és a közönség, a teli terem, áhítattal, könnyes szemmel hallgatta őket, emlékezvén a dallamok szerzőjére, aki egyike volt a legnagyobb magyaroknak."

6. Aranynak, a költőnek a bemutatása jelenlegi ismereteink szerint 1875-ben kezdődött egy német nyelvủ írás átvételével. ALEXANDER BERNÁT (1850-1927), az idővel neves filozófus, esztéta, színikritikus, szakfordító, tanár, akadémikus 1875-ben, tehát 25 évesen Literarische Charakterköpfe aus Ungarn címmel közreadott egy írást a nemzetközi érdeklődésre számot tartó német kiadványban (Unsere Zeit. Deutsche Revue der Gegenwart. Monatsschrift zum ...). Ezt részben idézve, részben „prózában elbeszélve” átvette a leginkább érdekelt finn lap, a Kirjallinen Kuukauslehti [Irodalmi folyóirat], Silmäyksiä Unkarin nykyiseen kirjallisuuteen [Pillantások a mai magyar irodalomra] címmel (N. N. 1875). A német „eredeti” Rákosi Jenőről szól, de a bevezetője nem akármilyen „pillantás”: rövid, velős áttekintés a magyar irodalomról és egyúttal Arany János ritka találó jellemzése. A finn cikk névtelen szerzője meg is jegyezte, hogy a német írás szerzője [B. Alexander] bizonyára magyar, aki jól ismeri a helyzetet, maga az írás pedig „,bevezetőként meglehetősen élvezetes [huvittava] és tárgyilagos [asiallinen] áttekintése a magyar irodalom jelenlegi [1875] helyzetének". Megtudható belőle, hogy a szellemi hösök csapata [tkp. szárnyaló csapata (henkisten sankarien parvi)] kikből áll: Petőfi, Jókai és Arany. „A harmadik ezek közül a zseniális férfiak közül, akik a forradalom [1848] előtt kezdték tevékenységüket, Juhana Arany, aki - miként sok máshoz hasonlóan ezen írásnak a szerzője is [B. Alexander] gondolja - Magyarország legkiemelkedőbb [etevin] költője. Csak nem annyira fürge [raitis] és elragadó [viehettävä], mint Petőfi, és nem olyan csillogó [loistava] és termékeny [tuottelias], mint Jókai; ő a legharmonikusabb [harmonillisin] és legelmélyültebb [syvin] közülük, és a magyar nyelv soha nem hangzott gazdagabban [rikkaammin] és szebben [kauniimmasti], mint az ő szájából."

6.1. Időrendben az Arany-életmü következő méltatása immáron JALAVA már említett terjedelmes nekrológja lett. A fordítások mennyiségét kevesellte, és rögtön néven is nevezte, kitől lehetne további fordításokat várni: „,Finn nyelvre Arany müvei közül még nem sok van lefordítva. A savokarjalaiak [kelet-finnországi egyetemisták] Koitar címủ albumában van a Toldiból néhány ének, dr. A. Genetz fordításában, és van az Unkarin Albumi címü könyvben három szép ballada: az Aune [Ágnes asszony], a Ritari Bor [Bor vitéz] és Klára Zács [Zách Klára], amelyek közül a két elsőt dr. Genetz fordította, és Paawo Cajander magiszter az utolsót. Nagyon kívánatos volna, hogy dr. Genetz, aki megmutatta, hogy az ilyenfajta munkára teljességgel képes [kykenewä], és aki hazánkban mindenkinél jobban tud magyarul, folytatná Arany müveinek finnre fordítását, ily módon téve lehetővé a finneknek is, hogy megismerjék ennek a nagy magyar költőnek zseniális munkáit."

Nézzük meg közelebbről ezeknek a Genetz-fordításoknak a történetét, tudván tudva, hogy az imént szorgalmazott nagyléptékủ folytatás elmaradt - 1889 utáni új Genetz-fordításról nem, „,csak” újrafordításról tudunk.

6.2. Arvid Genetz a Toldit huzamosabb magyarországi tanulmányútja idején, Budapesten fordította 1878-ban, és Budapestről küldte el Ahlqvistnak, aki 1879. január 17-én válaszolt neki: „Köszönet a Toldiért! Hol is tudnám kiadatni? 
A Kieletär [saját kiadványa] idén még elmarad" (Ahlqvist 1879/1982: 269, No. 276)]. Nem tudni, hogy a megköszönt Toldin az egész Toldi értendő-e; mi csak a később kinyomtatott énekeket ismerjük. Az Ahlqvist-leveleket közzétevő szerkesztő megjegyzést füzött a Toldi szóhoz: „Részlet a magyar költőnek, Aranynak (Arany János 1817-82) a mesés hőséröl, Toldiról és Magyarország középkoráról szóló verses eposzából [!], amelyet Genetz fordított finnre. A fordítás 1880-ban a Savo-karjalai diákszövetség Koitar-albumában jelent meg." Figyelemre méltó, hogy éppen Ahlqvist volt az első, aki a finn Toldi kiadási lehetőségén töprengett, ti. ő az egyetlen „,nagy finn”, akinek ,tudományos” magyarellenessége a saját, többszöri indoklásával - külön történet.

B. F. Godenhjelmnek a Kirjallinen Kuukauslehti 1880. októberi számában (1880. 10: 234) közzétett, nem túl lelkes, de azért biztató ismertetése így hangzott: „Az A. G. monogram [Arvid Genetz] leginkább a nyelvészet terén ismert, és a Koitarban is jelent meg már tőle nem egy értékes írás. A Koitarban most két verset tett közzé. Az egyik néhány részlet a magyar költő, Arany sajátos és nagyra értékelt elbeszélő költeményéből, a Toldiból. A fordító a Kalevala-runomittát [a kalevalai versmértéket] alkalmazta a fordításában, amely, meglehet, valóban a legmegfelelőbb a magyar nemzeti versformának. A. G. fordítása ad ugyan valamiféle fogalmat ennek a nevezetes költeménynek az előadásmódjáról [esitystavasta], de csak az egész müből tudnánk megismerni a szellemiségét és helyesen érteni a tartalmát, és ezért javasolnánk ennek a fordítómunkának a folytatását mindaddig, míg az egész Toldi meg nem jelenne finn ruhában [sic]".

1884-ben Budenz és Barna Ferdinánd - külön-külön - Genetzet felterjesztette akadémikusi tagságra (Tagajánlások... 1884). Barna az érdemek felsorolásában megjegyezte: „Fordított költeményeket és elbeszéléseket magyarból finnre”. Budenz szerint: „Dr. Genetz, ki a finn népköltészeti hagyományok újabb gyüjtésében is jelentékeny részt vett, költői tehetséggel is rendelkezik; egyebek közt van egy müfordítása (Arany Toldijából), melyben megmutatta, hogy lehetne a magyar eposzt a finn népeposz alakjába önteni”. (Kérdéses: a hogy itt kötőszó-e, avagy a hogyan rövid alakja.)

6.3. A Genetz-féle Toldiból ugyan nem jelent meg részlet Antti Jalava Unkarin Albumi [Magyar Album] címü könyvében, de azért a Toldi és Arany nem maradtak említetlenül. Az Album 1881-ben jelent meg, tehát - miként a Koitar is - még Arany életében. (A szalontai Arany-múzeumban van a Jalava által Aranynak dedikált példánya.) A 305. laptól az alkotók életrajza következik, elsőként Arany Jánosé (305-306), amely így végződik: „Az ő legnagyobb, legcsodálatosabb [ihanin] és legmesteribb [mestarillisin] múve mégis a nagy epikus trilógia, melynek első része a Toldi (meseszerü népi hős, a magyarok Herkulese) 1847-ben jelent meg, a második a Toldi szerelme, 1879, és a harmadik a Toldi estéje, és ezen elbeszélő költeményeinek köszönhetően az egész népe kedvence [koko kansansa lemmikki] lett. Minden magyar költő közül A[rany] ír a legszebb és leggondosabb nyelven [kirjoittaa kauniinta ja huolellisinta kieltä]."

Az Albumba tehát a Toldi nem került be, viszont ott jelent meg elöször Genetz két balladafordítása, az Ágnes asszony és a Bor vitéz. Saját egyéb müveivel együtt 1889-ben ő maga újra kiadta őket, szerzőként a költői nevén: Jännes, Arvi: Muistoja 
ja toiveita ystäville jouluksi [Emlékek és vágyálmok barátaimnak karácsonyra; Genetz 1889]. Ebben Genetz saját szövegváltoztatásai, föleg az Ágnes asszonyé jelentősek, és több szempontból is érdeklődésre tartanak számot, a Bor vitéz pedig egy 2001-ben készült fordítással összehasonlítva új megvilágításba kerülhet (mindezekről 1. alább). Ezt az 1889-es könyvet Severi Nuormaa újra kiadta 1918-ban, tehát a két Arany-ballada háromszor is hozzáférhetővé vált $(1881,1889,1918)$.

7. Az „egész” Toldi (1927) és a Toldi estéje (1937) csak mint kész fordítás lehetett meglepetés, ugyanis a finn sajtóban Aranyról meg szokták említeni, hogy nagy terjedelmü elbeszélő költeményei is vannak, néhol egyenesen eposznak nevezték őket, de talán éppen a terjedelem és a sok történelmi vonatkozás miatt, no meg a nyelv tudása nélkül sokáig nem akadt a fordításra, föleg nem egy-egy részének egészében fordítására vállalkozó. A trilógia nem teljes, ma is „csak” a Toldi és a Toldi estéje olvasható teljes terjedelmében finnül, mindkettő Otto Manninen (1872-1950) fordításában.

Manninen a finn költészet nagysága, író, műfordító, ahogy mondani szokás, „legenda már életében”. Magyar vonatkozásban a Heimokannel címü finnugor irodalmi sorozat második köteteként megjelent magyar népköltészeti fordításai (1926; Rokoni Lant címúként hírt adott róla a Turán 1926/1-2: 54), majd az egymást követő Petőfi-kötetei tették nevezetessé (nem véletlenül van szobra Kiskőrösön 2014. ápr. 16. óta). A Toldi 1927-ben jelent meg, a III. finnugor kultúrkongresszus tervezett évében (ez végül 1928-ban zajlott le Budapesten). A Toldit 1937-ben követte a Toldi estéje. Egy-egy ének mindkét Toldiból a Kalevalaseuran Vuosikirjában (a Kalevala Társaság Évkönyvében) is olvasható.

Manninen nem tudott magyarul, nyersfordításokból dolgozott. A finnországi magyarok közül például a már említett Weöres Gyula, Faragó József és Wichmann-né, illetve Bán Aladár segítségére számíthatott. Szinnyeinek tiszteletpéldányt küldött, benne ,,a fordító saját kezü megjegyzéseivel”. Talán Vikár Bélát is említeni lehetne, elvégre verset szentelt neki. A Toldi-kötetek finn és magyar fogadtatásáról, miként a két világháború közötti idők magyar-finn irodalmi kapcsolatairól YRJÖ VARPIO és SzOPORI NAGY LAJOS kötete (1990a, 1990b) körültekintően adott számot.

Ízelítőnek egy magyar példa. A Toldi estéje megjelenése (1937) után FARAGÓ JÓZSEF a Nyugatban (1938) méltatta a fordítót és a fordítást: „E sorok írója, aki az újabb magyar-finn fordítások mühelytitkait közvetlen közelből látta, sőt gyakran lépésről lépésre követhette, nem mond újat a hozzáértőknek, ha tárgyilagosan megállapítja, hogy költészetünk finn-nyelvủ megszólaltatói közül Otto Manninen szolgált rá legjobban a magyar irodalom hálájára. [...] Otto Manninen [...] túlfinomult, érzékeny, magábamélyülö, búsongó lélek és egyike a legnagyobb finn költőknek. A forma és a költői nyelv legvirtuózabb mestere. [...] A költő most megjelent fordításáról [...] csak azt ismételhetjük meg, amit a finn kritika már régebben megállapított Manninen korábbi átköltéseiről: »Manninen fordítása nem merő fordítás, hanem magasabbrendủ újjáteremtés, amilyenre csak Isten kegyelméből való poéták gondolhatnak.« Otto Manninen nélkül nem volna számbavehető Petőfije, Aranya, magyar népköltészete Finnországnak, vagy ha volna is, ilyen mü- 
vészi, ilyen tőrőlmetszett, ilyen magyar és ilyen finn - Manninenéhez fogható egészen biztosan nem lehetne."

2006 januárjában a kolozsvári Korunk finn számában PETRI NURMI megemlékezett Otto Manninenről, és a Petőfi-kötetek, valamint a kiskőrösi mellszobor említése után megjegyezte: „Igen kevés figyelmet szenteltek azonban egy másik magyar költőnek, Arany Jánosnak, akinek Toldi és Toldi estéje címü epikus költeményeit Manninen szintén kiválóan fordította (1927, 1937). Az Arany epikájában fellelhető ábrándvilág, kultúra, barbárság és lovagiasság Otto Manninen kecses és hajlékony alexandrinusain át ugyanolyan színes és zenei."

8. A fordításokat szemlélve nyilvánvaló, hogy magyarként aligha kell állást foglalnunk abban a kérdésben, hogy hány finn Arany-fordításnak kell, kellene vagy illene lennie, és föleg: milyennek kell vagy kellene lenniük. Jelenlegi ismereteink szerint 16 Arany-vers olvasható finnül, némelyik többféle fordításban, némelyik többféle kiadásban, és megjelent az „egész” Toldi és az „egész” Toldi estéje, bizonyos énekeik újrakiadásként is, és számon tartjuk az imént említett gyerekirodalmi kiadványt, amelyben kétféle új fordítású Arany-részlet van.

Milyenek ezek a fordítások? Az eredeti művek és a müfordítások viszonyáról a mindkét nyelven tudók is eltérő módon szoktak állást foglalni. Mint általánosságban, az Arany-fordításokban is vannak kiváló megoldások, vannak kevésbé kiválóak, és néha akad alapos félreértés is, de arra is akad példa, hogy a fordítás - szerintünk - frappánsabb az eredetinél (1952, Civilizáció, Elvi Sinervo fordítása). Továbbá a mi esetünkben is fel lehet, sőt fel kell tenni a kérdést: mikor, mitől avul el egy müfordítás, mi készteti az újabb fordítót a próbálkozásra?

Itt és most csak néhány megjegyzés, „mutatóba” ebből a témakörből. Általánosságban állítható, hogy a finn nyelv sokkal gyorsabban változik, mint a magyar, a nyelvi normák ,kodifikálása” egyre nagyobb szakmai gond, tehát mindenképpen olyan kritikusra, kutatóra van/lenne szükség, aki a bármikori Arany-fordítások és a magyar eredeti nyelvezetében egyaránt otthonosan mozog, aki például a ma finnül Hyvää iltaa!' Jó estét!' köszöntést hallván nem lepődik meg, ha a Toldi estéje finn címében az odaillőbb, régiesebb és költőibb ehtoo szót találja: Toldin ehtoo (Manninen 1937, de JALAVA toim. 1881: 306, Toldin ilta).

A finn nyelv szükség szerinti „kiigazítását” Otto Manninennek (is) többen felrótták. Nehezítette az értést és rontotta az élvezetet a szótövek és toldalékok lerövidítése, amely technikailag sokféle vesszőben vagy hiányjelben nyilvánult meg. Bántónak találták a szórend gyakori megváltoztatását (magyar példa: Botond beveri Bizánc kapuját helyett Botond beveri kapuját Bizáncnak).

Segítenek a jegyzetek, lábjegyzetek - ilyen tartalmi-technikai megoldás például a Zách család története az Unkarin Albumiban vagy a Bor vitéz első Genetz-féle változatában a pacsirta „,kilétének” lábjegyzete, a Rendületlen fordításához füzött Vörösmarty-jegyzet. A Bor vitézbeli m. nászkíséret megfelelöje Genetznél olyan finn szó, amelyet a neki kortárs finnek is anyanyelvjárásuktól függően értettek meg.

Az ún. reáliák fordítását nagy leleménnyel oldották meg, például a hajdú a törvény embere, Bence kulacs-a közérthetően taskumatti lett (ez lapos, fém, zsebben hordható, ma virágkorát élő alkoholszállító eszköz). A tikkadt szöcske- 
nyájak sem okoztak gondot, elvégre a szöcske szó finnül kedves női név is lehet. A Hé! paraszt típusú vokatívusz már nehezebb feladat, mert a finnben a 'paraszt' jelentésủ szónak sosem volt sértő mellékjelentése, és a fiam, Ágnes mit míveltél megszólításnak is nehéz lehetett megtalálni a nyelvi-stilisztikai megfelelöjét.

A versforma, a versmérték többnyire nem okozott nehézséget, a megszokott hazai (finn) formához ,idomítást” elkerülhették, föleg a kalevalai versmérték (f. kalevalamitta), a felező nyolcas és a mindkét nyelvben első szótagi szóhangsúly bizonyult kölcsönösen elönyösnek. A Bor vitéz sorismétléses maláj versformája a fordítóknak kihívás volt. Köztudomású, hogy az egész balladában csak négy - többnyire gond nélkül skandálható - sor nem ismétlődik, ezek nem tartoznak össze, de egymás mellé írva a finnül tudóknak és a nem-tudóknak sem érdektelenek: Ködbe vész a nap sugára; Bor vitéz kap jó lovára; Bagoly sír a bérci fok közt; Halva lelték a romok közt. Arvid Genetz $\left(1881^{1}\right.$ Ritari Bor, $1889^{2}$ Bor ritari) fordításában: Päivä pilviin piil', on ilta; Ritar' lausuu ratsahilta; Huuhkain huutaa vuoristosta; Kuollut löyttiin rauniosta. Sinikka Pohjola (2001 Ritari Bor) fordításában: Päivänsäde sumuun hukkuu; Ratsun selkään Bor nyt hyppää; pöllö itkee jyrkänteellä; raunioilta ruumis löytyi.

A fordításokhoz füzött fordítói magyarázatok és értelmezések egyike különös figyelemre tarthat számot. SINIKKA POHJOLA a már említett két fordítása közül a Bor vitéz új, modern fordítása mellé rövid, de ,távlatos” magyarázatot [esittely] füzött: Arany ,a nemzeti költőnek, Petőfinek a kortársa és vele együtt vett részt 1848-ban a Habsburg-ellenes forradalomban. Mủvei közül ismertebbek epikus költeményei, a Toldi, a Buda halála és a történelmi balladák sora (többek között A walesi bárdok). Lükő Gábor hívta fel írásaiban a figyelmet arra, hogy Arany a megindító és drámai Bor vitéz balladát hat [!] évvel az után írta, hogy az Ausztria által behívott orosz haderő segítségével a magyar szabadságharcot leverték. A Bor név egyértelmüen a lengyelekre utal [nimi Bor viittaa selvästi puolalaisiin]. Ebből a szempontból úgy gondolhatjuk, hogy a költő a balladájával a lengyel-magyar szövetség lehetőségének semmivé válását is siratja [runoilija balladissaan suree myös mahdollisen puolalaisunkarilaisen liittoutuman raukeamista]." A lengyeleknek ez a fajta felbukkanása (a Bor vitézzel kapcsolatban) feltehetően KÁDÁR GYÖRGY többféle és többszöri (magyar, orosz, finn) kiadást megért könyvéböl származó nézet, és nála is más szerző véleményeként: „A magyar nép magára maradásáról müvészi szimbólumokban Arany János is írt. A költő az itt következő balladát [a Bor vitézt] - Lükő szerint - a magyar szabadságharc és a lengyel-magyar összefogás meghiúsulásának hatása alatt, hét [!] évvel a világosi fegyverletétel után írta" és az ide vonatkozó lábjegyzet szerint: az 1831-es lengyel felkelésről van szó (KÁDÁR 2010: 97, 183. jegyzet). A Bor vitéz másfajta új értelmezését csak friss kuriózum volta miatt említjük: HOVÁNYI MÁRTON a Petőfi Irodalmi Múzeumban 2017. febr. 26-án, az Arany-emlékév egyik megnyitóján tartott előadásában logikus gondolatmenettel felvetette a Bor vitéz alkohol- vagy drogmámoros képzelményképként értelmezhetőségének lehetőségét.

A magyar irodalom finnre fordításának kezdetén nemzetközi divat volt a nevek „honosítása” (vö. Verne Gyula vagy lásd az emléktáblát a budapesti Puskin Sándor utca elején). A Toldi első fordításában Miklós, György, Bence még Niilo, Yrjö, Pentti névre hallgatott, sőt volt a Toldi-család birtokának is saját finn földrajzi neve: Toldila 
(vö. Karjala, Kalevala). Az Ágnes asszonyt finnre először Genetz fordította, Aune volt a címe; másodszor saját kiadásában, változtatásokkal adta közre, ekkor már Ágnes a cím. A Genetz-család gyermekeinek a keresztnevei sajátos tudatosság nyomait őrzik: Lauri Árpád Magyarországon született, itt halt meg gyerekbetegségben; Aune szintén gyerekbetegségben halt meg, és az édesapja nagy szívfájdalmában inkább Ágnes-t írt az újra kiadott vers élére; Niilo Edward nevét hallva lehetetlen nem gondolni Toldi Miklósra és Edward királyra, bár nincs tudomásunk arról, hogy Genetz A walesi bárdokat lefordította volna. Sosem lehet tudni, egy vers mikor mivel válthat ki érdeklődést. Most, a brexit idején például kérdéses (lehetne), hogy Edvard - angol király-e (lásd finnül 1970-ben) vagy brit király-e (lásd 1952-ben).

9. Örök kérdés, hogy egy-egy nemzeti irodalom mennyire ad hiteles képet az adott nemzet fiairól. Minden finn olyan, amilyennek a finn népköltészet, a nemzeti eposz vagy a finn klasszikusok leírták, megénekelték? Mennyiben nemzeti Arany, múvei mennyire tükrözik a magyart, a magyar jellemet, a magyar identitást? Olyanok-e a magyarok, mint Toldi: türte Miklós, türte, ameddig türhette, aztán elrepül(t) a nagy kő...?

Arany Jánost már eleve klasszikusként ismerték meg a finnek, és ez a klasszikusság mindmáig megmaradt. Kezdettől fogva megbecsült klasszikus értékként tekintettek rá, nem üstökösként, hanem fényes állócsillagként, nagy tisztelettel, elismeréssel, csakhogy a nemzetközi porondra, függetlenségre, saját és egyben korszerü nyugatias mủveltségre törekvő, később magukat ilyennek bizonygató és ilyennek bizonyuló finnek részéről már csaknem az ismerkedés kezdeténél tudható és érezhető volt az ellentmondás, hogy bármennyire szép, emelkedett, eszményi - nem időszerü, sem a tartalom, sem a (vers)forma -, „,csak” klasszikus! Maga Arany ezt úgy fogalmazta meg, hogy „kiöregedtem kortársaim közül”.

\section{Melléklet}

\section{1. táblázat}

Arany János finnül olvasható versei

\begin{tabular}{|l|l|l|}
\hline \multicolumn{1}{|c|}{ Magyar cím } & \multicolumn{1}{|c|}{ Finn cím } & \multicolumn{1}{c|}{ A megjelenés ideje, a vers fordítója } \\
\hline $\begin{array}{l}\text { A walesi } \\
\text { bárdok }\end{array}$ & $\begin{array}{l}\text { Walesin } \\
\text { runonlaulajat } \\
\text { Walesin bardit }\end{array}$ & $\begin{array}{l}\text { 1952, Aira Sinervo } \\
\text { 1970, Toivo Lyy }\end{array}$ \\
\hline Ágnes asszony & $\begin{array}{l}\text { Aune } \\
\text { Agnes }\end{array}$ & $\begin{array}{l}\text { 1881 Arvid Genetz } \\
1889^{1}, 1918^{2} \text {, Arvi Jännes/Arvid Genetz }\end{array}$ \\
\hline Bor vitéz & $\begin{array}{l}\text { Ritari Bor } \\
\text { Bor ritari } \\
\text { Ritari Bor }\end{array}$ & $\begin{array}{l}\text { 1881, Arvid Genetz } \\
\text { 1889, Arvi Jännes/Arvid Genetz } \\
\text { 2001, Sinikka Pohjola }\end{array}$ \\
\hline Civilizáció & Sivilisatio & 1952, Elvi Sinervo \\
\hline Családi kör & Perhepiiri & $\begin{array}{l}\text { 1952, Elvi Sinervo és Aira Sinervo } \\
\text { 1970, Toivo Lyy } \\
\end{array}$ \\
& & 1992, T. Lahdelma (a 9-12. versszak nélkül) \\
\hline Dal fogytán & Laulun laantuessa & 1952, Elvi Sinervo \\
\hline
\end{tabular}




\begin{tabular}{|c|c|c|}
\hline Epilógus & Epilogi & 1970, Toivo Lyy \\
\hline Intés & Neuvo & 1952, Elvi Sinervo \\
\hline $\begin{array}{l}\text { Letészem a } \\
\text { lantot }\end{array}$ & Jo jätän luuttuni & 1970, Toivo Lyy \\
\hline Magányban & Yksinäisyydessä & 1970, Toivo Lyy \\
\hline Mátyás anyja & Mátyásin äiti & 2003, Sinikka Pohjola (kétnyelvü) \\
\hline Népdal & Kansanlaulu & 1970, Toivo Lyy \\
\hline Rendületlenül & 'Järkkymättä' & 1952, Elvi Sinervo \\
\hline $\begin{array}{l}\text { Szondi két } \\
\text { apródja }\end{array}$ & \begin{tabular}{|l|} 
Szondin \\
kaksi paashipoikaa
\end{tabular} & 2012, Eliisa Pitkäsalo \\
\hline $\begin{array}{l}\text { Válasz } \\
\text { Petöfinek }\end{array}$ & Vastaus Petőfille & 1970, Toivo Lyy \\
\hline Zách Klára & Klara Zács & $1881^{1}, 1914^{2}$, Paavo Cajander \\
\hline Toldi & Toldi & $\begin{array}{l}\text { 1880; 1., 2. [próza], 3., 4., 5. [próza], 6. ének; A. } \\
\text { G. [Arvid Genetz] } \\
\text { 1889, 4. ének }{ }^{2} \text {, A. Jännes } \\
\text { 1927, Otto Manninen } \\
\text { 1927, 5. ének }{ }^{2} \text {, Kalevalaseuran Vuosikirja } 7\end{array}$ \\
\hline Toldi estéje & Toldin ehtoo & $\begin{array}{l}\text { 1934, 4. ének, Kalevalaseuran Vuosikirja } 14 \\
\text { 1937, Otto Manninen } \\
\text { 1992, Tuomo Lahdelma, 1-4. sor (címe: az 1. sor) }\end{array}$ \\
\hline
\end{tabular}

\section{2. táblázat}

Arany János verseinek finn fordítói

\begin{tabular}{|l|l|}
\hline \multicolumn{1}{|c|}{ Fordító } & \multicolumn{1}{c|}{ A lefordított versek } \\
\hline Cajander, Paavo & Zách Klára \\
\hline Genetz, Arvid / Jännes, Arvi & $\begin{array}{l}\text { Ágnes asszony; Bor vitéz; a Toldiból az 1., 2. (próza), } \\
\text { 3., 4., 5. (próza), 6. énekek }\end{array}$ \\
\hline Lahdelma, Tuomo & $\begin{array}{l}\text { Családi kör (a 9-12. versszak nélkül); } \\
\text { a Toldi estéje első négy sora }\end{array}$ \\
\hline Lyy, Toivo & $\begin{array}{l}\text { A walesi bárdok; Családi kör; Epilógus; Letészem a } \\
\text { lantot; Magányban; Népdal; Válasz Petőfinek }\end{array}$ \\
\hline Manninen, Otto & Toldi; Toldi estéje \\
\hline Pitkäsalo, Eliisa & Szondi két apródja \\
\hline Pohjola, Sinikka & Bor vitéz; Mátyás anyja \\
\hline Sinervo, Aira & A walesi bárdok \\
\hline Sinervo, Elvi & $\begin{array}{l}\text { Családi kör; Civilizáció; Dal fogytán; Intés; } \\
\text { Rendületlenül }\end{array}$ \\
\hline
\end{tabular}

Kulcsszók: A. Genetz, A. Jalava, O. Manninen, A. Turtiainen, T. Lyy, T. Lahdelma, S. Pohjola, E. Pitkäsalo, A walesi bárdok, Bor vitéz, Ágnes asszony, Toldi, Toldi estéje, Szondi két apródja, Mátyás anyja. 


\section{Hivatkozott irodalom}

A. G. [Genetz, Arvid] 1880. Toldi. Arany'in unkarin-kielestä suomentanut A. G. Koitar.

Savo-karjalaisen Osakunnan Albumi 3. G. W. Edlund, Helsinki. 127-166.

Ahlqvist, August 1879/1982. Ahlqvistin kirje Genetzille 17. I. 1879. In: HIRVONEN, MAIJA-

LAHIKAINEN, KAISU toim., Kirjeet: kielimiehen ja kaukomatkailijan viestejä 18451889. SKS, Jyväskylä. 267-269.

Cajander, Paavo 1914. Runoelmia. Toim. A. V. KosKIMIES. Kirja, Helsinki.

FARAGÓ JÓZSEF 1938. Toldi estéje - finnül „Toldin ehtoo” - O. Manninen fordítása. Nyugat 1938/4: 307-309.

FÜZFA BALÁzS szerk. 2015. Az ötven legszebb magyar vers (Antológia). Nemzetek Háza Collegium Fenno-Ugricum, Badacsonytördemic.

GÁBORI KOVÁCS JÓzSEF 2017. Tudományszervezö költő az Akadémián. http://mta.hu/[-] tudomany_hirei/tudomanyszervezo-kolto-az-akademian-arany-janos-es-az-[-] mta-107424 (2017. 11. 16.)

GAZDA ISTVÁN 2008. Az akadémikus melegre vágyik. A fótitkár rímmentes napjai. In: FORRAI JUDIT et al. szerk., Ditor ut ditem. Tanulmányok Schultheisz Emil profeszszor 85. születésnapjára. Magyar Tudománytörténeti Szemle Könyvtára 75. Magyar Tudománytörténeti Intézet - Semmelweis Orvostörténeti Múzeum, Könyvtár és Levéltár, Budapest. 207-232.

Genetz, Arvid [Jännes, Arvi] 1889¹. Muistoja ja toiveita. Ystäville jouluksi. Weilin \& Göös Osakeyhtiö, Helsinki.

Genetz, Arvid [Jännes, Arvi] $1918^{2}$. Muistoja ja toiveita. Ystäville jouluksi. Toim. SEVERI NuORMAA. Weilin \& Göös Osakeyhtiö, Helsinki.

GEREVICH-KOPTEFF ÉVA 2003. Madách Az ember tragédiája és finn fordításai a nemzeti kultúrák, az irodalmi recepció és fordításelemzés tükrében. Castrenianumin toimitteita 61. Folia Hungarica 12. Helsingin yliopiston suomalais-ugrilainen laitos Suomalais-Ugrilainen Seura, Helsinki.

HovÁNYi MÁRTON 2017. Bordal vagy gyászinduló? A Bor vitéz értelmezése. Előadás a Petőfi Irodalmi Múzeumban, 2017. február 21-én.

JALAVA, ANTTI toim. 1881. Unkarin Albumi. Weilin ja Göös, Jyväskylä.

KÁDÁR GYÖRGY 2008. Egy lehetséges uráli filozófia. Püski, Budapest.

KERESZTURY DEZSŐ 1982. János Arany (1817-1882) - Unkarin Goethe. Suomi-Unkari 1982/3: 4-5, 1982/4: 4-5.

LAHDELMA, TuOMO 1992. Viluinen kuningas. Käännöksiä ja mukaelmia unkarilaisesta lastenrunoudesta. Valikoinut ja mukaellen suomentanut. Atena, Jyväskylä.

LYY, TOIVO toim. 1970. Unkarin lyyra. Unkarilaista lyriikkaa keskiajalta nykyaikaan. Unkarilaisten asiantuntijain valikoimasta aineistosta toimittanut ja suomeksi runoillut. SKS, Helsinki.

N. N. 1875. Silmäyksiä Unkarin nykyiseen kirjallisuuteen. Kirjallinen Kuukauslehti 1875/9-10: 224-236.

NURMi, PETRI 2006. Otto Manninen - a magyar líra fordítója. Korunk 17/1: 87-89.

Pitkäsalo, Eliisa 2012. Szondin kaksi paashipoikaa. In: A 12 legszebb magyar vers. Válogatta FÜZFA BALÁZS, szerk. PUSZTAY JÁNOS. NH-Collegium Fenno-Ugricum LiteratUral Badacsonytomaj. 87-89.

Pohjola, Sinikka 2001. Arany János: Ritari Bor. Suom. ja esittely. Suomi-Unkari 2001/3: 11. 
Pohjola, Sinikka 2003. Arany János: Mátyás anyja - Mátyásin äiti. Suomennos. Esittely Kovács Magdolna. Suomi-Unkari 2003/2: 21.

RÄIKKÖNEN, ERKKI 1924. Heimokirja. Otava, Helsinki.

SZEGÖ JÁNOS 2012. Katsaus unkarilaiseen kirjallisuuteen. Suomennos Anna Tarvainen. Zaft, Budapest.

SzÍJ ENIKÖ 1991. A finnugor néprokonsági eszme az 1920-30-as években. In: KINCSES NAGY ÉVA szerk., Östörténet és nemzettudat 1919-1931. Magyar Östörténeti Könyvtár 1. JATE Magyar Östörténeti Kutatócsoportja - Balassi Kiadó, Szeged. 72-88.

Tagajánlások az I. osztály részéről. Dr. Genetz Arvid. A Magyar Tudományos Akadémia Értesitője 1884. 18: 115-116.

Tietosanakirja = Tietosanakirja 1. $(A-C)$. Tietosanakirjaosakeyhtiö - Kustannusosakeyhtiö Otava, Helsinki, 1909.

TIIRIKAINEN, SANNA 2008. Unkarilaisia kirjailijoita. http://suomiunkari.fi/tietoa-[-] unkarista/2008/10/unkarin-kirjallisuus (2017. 02. 28.)

TURTIAINEN, ARVO toim. 1952. Vapauden tulet. Kansankulttuuri, Helsinki.

VARPIO, YRJÖ - SZOPORI NAGY LAJOS 1990a. Ismerkedö ismerösök: a magyar irodalom fogadtatása Finnországban - a finn irodalom fogadtatása Magyarországon 19201986. Magyar-finn közös kutatás. [A finn nyelvü rész(eke)t magyarra ford. Szopori Nagy Lajos]. OSZK Könyvtártudományi és -módszertani központ, Budapest.

VARPIO, YRJÖ - SzOPORI NAGY, LAJOS 1990b. Suomen ja Unkarin kirjalliset suhteet vuosina 1920-1986. [A magyar nyelvü rész(eke)t finnre ford. László, Tiina.] Suomi 153. SKS, Helsinki.

WiCHMANN, IRENE 2009. Petöfi Sándor költészete. THL 2009/1-2: 66-78.

WiChMANN, IRENE 2015. Unkarin kirjallisuus 1800-luvun Suomessa Petöfin ja Jókain teosten valossa. https://helda.helsinki.fi/bitstream/handle/10138/157429/unkarink.[-] pdf? sequence $=1$ (2017. 02. 28.)

\section{János Arany's reputation with the Finns}

Finnish readers have come to know János Arany, the man and his poetry, in a variety of ways since 1875. From articles in the Finnish press and from the growing number of translations of his poems, it was evident from the very beginning that he is a classic poet of Hungarian literature whose oeuvre should be widely known. The various stages of the history of the translations are aligned with events in Finnish history and in that of Hungarian-Finnish contacts: the 1870s and 80s (the time of political "fennomania"), the 1920s and 30s (the first decades of Finnish independence), the 50s, the 70s, and the early 2000s. At any Hungarian jubilee commemoration in Finland, along with that of Petöfi, more widely known as the "mover and shaker" of Hungarian poetry, János Arany's name invariably crops up. At the moment, Finnish translations of 16 of Arany's poems are known; some poems have more than one Finnish versions, and some have been published repeatedly; Toldi (1927) and Toldi estéje (Toldi's Evening, 1937) were published in Finnish in their entirety.

Keywords: A. Genetz, A. Jalava, O. Manninen, A. Turtiainen, T. Lyy, T. Lahdelma, S. Pohjola, E. Pitkäsalo, A walesi bárdok (The Bard of Wales), Bor vitéz (Knight Bor), Ágnes asszony (Matron Agnes), Toldi, Toldi estéje (Toldi's Evening), Szondi két apródja (The Two Pages of Szondi), Mátyás anyja (The Mother of King Matthias). 